\title{
Effects of lead poisoning in children- A narrative review
}

\author{
Efeitos da intoxicação por chumbo em crianças- Uma revisão narrativa \\ Efectos de la intoxicación por plomo en los niños- Una revisión narrativa
}

Received: 05/28/2021 | Reviewed: 06/06/2021 | Accept: 06/10/2021 | Published: 06/25/2021

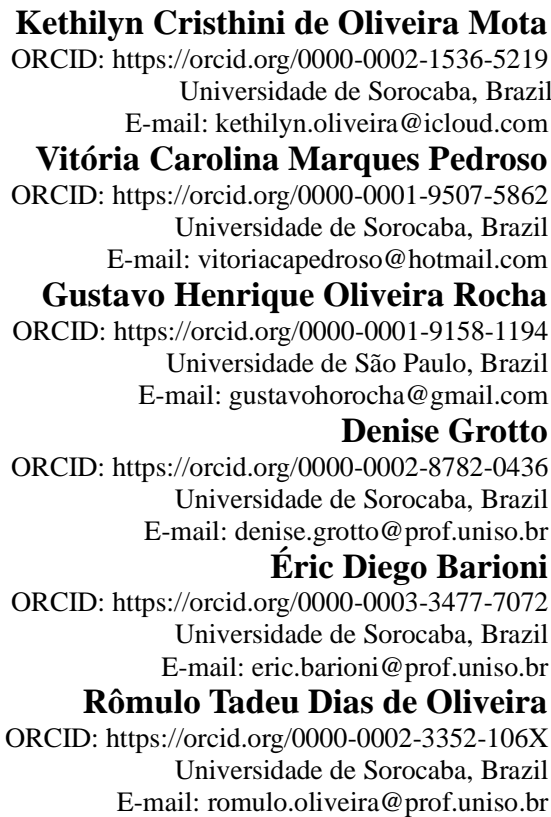

\begin{abstract}
Objective: exposure of children to lead still poses a major health concern for public health agencies worldwide. This work aims to describe which are the symptoms most frequently associated with lead exposure in children, providing further basis to both researchers and policy makers to better guide future efforts aimed at addressing such issue. Methods: a systematized review of articles on the present topic published between June 2005 and February 2021 was carried out. Results: data described in the reviewed articles show a clear relationship between blood lead levels and hematopoietic and cognitive effects in children exposed to either low or high levels of lead. Concerning effects can be identified at blood lead levels above $4 \mu \mathrm{g} / \mathrm{dL}$, and the highest blood lead level reported was of $88.39 \mu \mathrm{g} / \mathrm{dL}$. Conclusions: lead poisoning of children continues to be a serious public health issue worldwide, especially for those in South America, and health agencies and policy makers alike would benefit from more studies describing areas where lead exposure is high as well as describing how children have been responding to such exposure in the past years in order to better combat this issue.
\end{abstract}

Keywords: Lead; Poisoning; Children; Symptoms.

\section{Resumo}

Objetivo: a exposição de crianças ao chumbo ainda representa uma grande preocupação de saúde para agências de saúde pública em todo o mundo. Este trabalho tem como objetivo descrever quais são os sintomas mais frequentemente associados à exposição ao chumbo em crianças, fornecendo uma base adicional para pesquisadores e formuladores de políticas para melhor orientar os esforços futuros no sentido de abordar essa questão. Métodos: foi realizada uma revisão sistematizada de artigos sobre a temática publicados entre junho de 2005 e fevereiro de 2021. Resultados: os dados descritos nos artigos revisados mostram uma relação clara entre os níveis de chumbo no sangue e os efeitos hematopoiéticos e cognitivos em crianças expostas a níveis baixos ou altos de chumbo. Os efeitos podem ser identificados em níveis de chumbo no sangue acima de $4 \mu \mathrm{g} / \mathrm{dL}$, e o maior nível de chumbo no sangue relatado foi de $88,39 \mu \mathrm{g} / \mathrm{dL}$. Conclusões: o envenenamento por chumbo em crianças continua a ser um sério problema de saúde pública em todo o mundo, especialmente para aqueles na América do Sul, e agências de saúde e legisladores se beneficiariam de mais estudos descrevendo áreas onde a exposição ao chumbo é alta, bem como descrevendo como as crianças têm sido responder a essa exposição nos últimos anos para melhor combater esse problema.

Palavras-chave: Chumbo; Envenenamento; Crianças, Sintomas. 


\section{Resumen}

Objetivo: la exposición de los niños al plomo sigue siendo un problema de salud importante para las agencias de salud pública en todo el mundo. Este trabajo tiene como objetivo describir cuáles son los síntomas asociados con mayor frecuencia a la exposición al plomo en los niños, proporcionando una base adicional tanto para los investigadores como para los responsables de la formulación de políticas para orientar mejor los esfuerzos futuros destinados a abordar este problema. Métodos: se realizó una revisión sistematizada de artículos sobre el presente tema publicados entre junio de 2005 y febrero de 2021. Resultados: los datos descritos en los artículos revisados muestran una clara relación entre los niveles de plomo en sangre y los efectos hematopoyéticos y cognitivos en niños expuestos a niveles bajos o altos de plomo. Se pueden identificar efectos preocupantes con niveles de plomo en sangre superiores a $4 \mu \mathrm{g} / \mathrm{dL}$, y el nivel más alto de plomo en sangre informado fue de $88,39 \mu \mathrm{g} / \mathrm{dL}$. Conclusiones: la intoxicación por plomo en los niños sigue siendo un problema grave de salud pública en todo el mundo, especialmente para los de América del Sur, y las agencias de salud y los responsables de la formulación de políticas se beneficiarían de más estudios que describan las áreas donde la exposición al plomo es alta y que describan cómo han sido los niños. respondiendo a tal exposición en los últimos años con el fin de combatir mejor este problema.

Palabras clave: Plomo; Intoxicación; Niños, Síntomas.

\section{Introduction}

Lead is a toxic heavy metal which contaminates soil, water and air; it is distributed via the bloodstream after absorption resulting in long-term accumulation (Liu et al., 2013), damaging human organs and tissues, affecting especially the development of the central nervous system in children (Lanphear et al., 2005). On a global scale, lead is considered one of the most harmful pollutants to human health, and it is assumed that there are about 10 million people living in contaminated sites (Costa et al., 2012) and about 800 million children are estimated to have blood lead levels $>5 \mu \mathrm{g} / \mathrm{dL}$, which demands regional intervention by health services according to the World Health Organization (WHO) (UNICEF, 2020).

According to the US Centers for Disease Control and Prevention (CDC), children blood lead levels above $10 \mu \mathrm{g} / \mathrm{dL}$ are considered to be extremely alarming (Freudenrich, 2009). In Brazil, although there are no data available on lead exposure in children, several authors suggest this is indeed a serious public health issue due to the widespread environmental contamination with lead and due to its continued use in Brazilian industry. In addition, it is difficult to make estimates about lead exposure in Brazil, since the existence of informal working activities which employ lead and environmental liabilities must be considered (Mayans, 2019; Padula et al., 2006). Dascanio et al. (2016) report that lead levels in the blood of children above the recommended by the CDC is generally related to the fact that such children live in areas surrounding mines and lead smelters, which eventually has led to tragic incidents such as those in Santo Amaro in the state of Bahia and in Paulínia, Cubatão, Caçapava and Bauru in the state of São Paulo (Dascanio et al., 2016).

Children are innately more vulnerable to various toxic elements (Landrigan et al., 2002). In this sense, children are more likely to absorb and accumulate lead, thus making them more susceptible to its harmful effects (Gao et al., 2017), which can lead to permanent learning impairments and development of behavioral disorders (Lanphear et al., 2005).

Lead modifies several biochemical processes, causing gastrointestinal effects by damaging smooth muscles of the intestine; neuromuscular effects by causing demyelination and axonal degeneration, impairing psychomotor and neuromuscular functions; cardiovascular effects by inducing chronic myocarditis syndrome associated with hypotonia or hypertonia; kidney effects by causing irreversible disorders of the renal tubules and irreversible interstitial nephropathy; hepatic effects by interfering with biotransformation processes, decreasing the levels of cytochrome P450 and the activity of glutathione-S-transferase leading to toxic hepatitis. These effects, however, are only observed in severe intoxications (Schifer et al., 2005).

The hematological system is an important target for lead toxicity. At higher levels, lead exposure results in decreased synthesis of heme and subsequent anemia associated with a decreased production of erythrocytes (Souza \& Tavares, 2009); this effect is due to lead inhibiting the enzyme delta-aminolevulin dehydratase ( $\delta$-ALAD) (Services, 2002). Moreira et al., 2004 add that the effects related to hematopoiesis leading to anemia evoked by lead exposure are a result of their toxic action on erythropoietic cells in the bone marrow. Children exposed to high levels of lead often present iron deficiency anemia, 
microcytic hypochromic anemia and microalbuminuria (Riera et al., 2012). Lead can also affect several enzymatic systems, by binding to sulfhydryl groups of enzymes resulting in their inactivation and modifying the properties of other metals in their structures (Services, 2002).

Several studies indicate that blood lead concentrations above $10 \mu \mathrm{g} / \mathrm{dl}$ are related to neurobehavioral problems, visual impairment, changes in speech and psychological and developmental deficits, thus leading to impairment of intellectual development of children and development of specific behavioral syndromes, such as hyperactivity (Chiodo et al., 2004; Dascanio et al., 2012). Mental confusion associated with headaches and behavioral changes are also signs of early encephalopathy, which can progress to consciousness disruptions, stupor and seizures. While encephalopathy can fortunately be treated, however, a high percentage of children who recover from clinical encephalopathy still live on suffering from severe cognitive, attention and behavioral disorders. Alongside cognitive effects, as described, children may also suffer hematopoietic effects such as normocytic hypochromic anemia which can cause abdominal pain and arthralgia(Needleman, 2004; Souza \& Tavares, 2009).

High levels of lead in the environment are still detected in various areas worldwide and children living in these areas are very sensitive to exposure to this metal. Studies associating blood lead levels and symptoms in children are scarce and are spread throughout different regions of the globe. This way, the aim of this work is to compile these studies in order to create a comprehensive list of which symptoms are more frequently associated with lead exposure in children. This should allow both researchers and policy makers to better conduct future efforts to address such issue.

\section{Methodology}

\section{Search strategy for articles}

A systematized narrative review was carried out searching for scientific articles published in journals with strict editorial policy from June 2005 to February 2021. The search was carried out in the electronic databases SciELO - Brazil (Scientific Electronic Library Online), PubMed (US National Library of Medicine), LILACS (Latin American and Caribbean Literature in Health Sciences), and PsycInfo (American Psychological Association). Terminologies used were registered in the Health Sciences Descriptors, created by the Virtual Health Library from Medical Subject Headings of the US National Library of Medicine, which allows the use of common terminology in Portuguese, English and Spanish. The terms used in the search were "lead", "poisoning" and "children"

\section{Selection of studies and minimization of search bias}

Two researchers (KCOM and VCMP) independently searched for articles by accessing, at first, the title and abstract. Articles that did not fit the eligibility criteria and duplicate articles were excluded. Any disagreement between the two authors was resolved by a third reviewer (RTDO). The full text of the remaining articles was accessed to determine whether they would be included or not in the work.

\section{Inclusion and exclusion criteria}

Only articles that described effects caused by lead poisoning at levels above $5 \mu \mathrm{g} / \mathrm{dL}$ on children aged 0 to 13 years were included in the study (according to the Child and Adolescent Statute, in Brazil, every person up to 12 years is considered a child (IBGE, n.d.)). The reference value for blood levels has been established by the CDC in 2012 and it was based on the 97.5 percentile of the distribution of lead in blood according to the data from the National Health and Nutrition Survey (NHANES) in children aged from 1 to 5 years (Prevention, 2020). Articles which did not report blood lead measurements or which reported the effects of exposure to other metals alongside lead were excluded from the study. 


\section{Data compilation}

A flowchart (whose main objective is to help authors improve reporting systematic and systematized reviews (Altman, 2015)), was built including all stages of data collection in accordance with PRISMA guidelines (Preferred Reporting Items for Systematic reviews and Meta-analyses) (Page et al., 2021); RTDO provided methodological support and also decided on any divergences regarding data collection between first and second authors, acting as a third reviewer (figure 1).

\section{Results and Discussion}

\section{Literature search results}

The initial search identified 1841 articles: 1711, 45, 10 and 75 from PubMed, SciElo, PsycInfo and LILACS databases, respectively. After excluding 37 duplicate articles and 234 review articles, 1570 articles remained. Of these, 1542 articles were excluded by title and abstract. After the initial selection, 28 articles were selected for further detailed reading and 18 were excluded due to not fitting the inclusion criteria. At the end of the analysis, 10 articles were selected for qualitative synthesis.

Figure 1. PRISMA research flowchart comprising literature review and selection of studies.
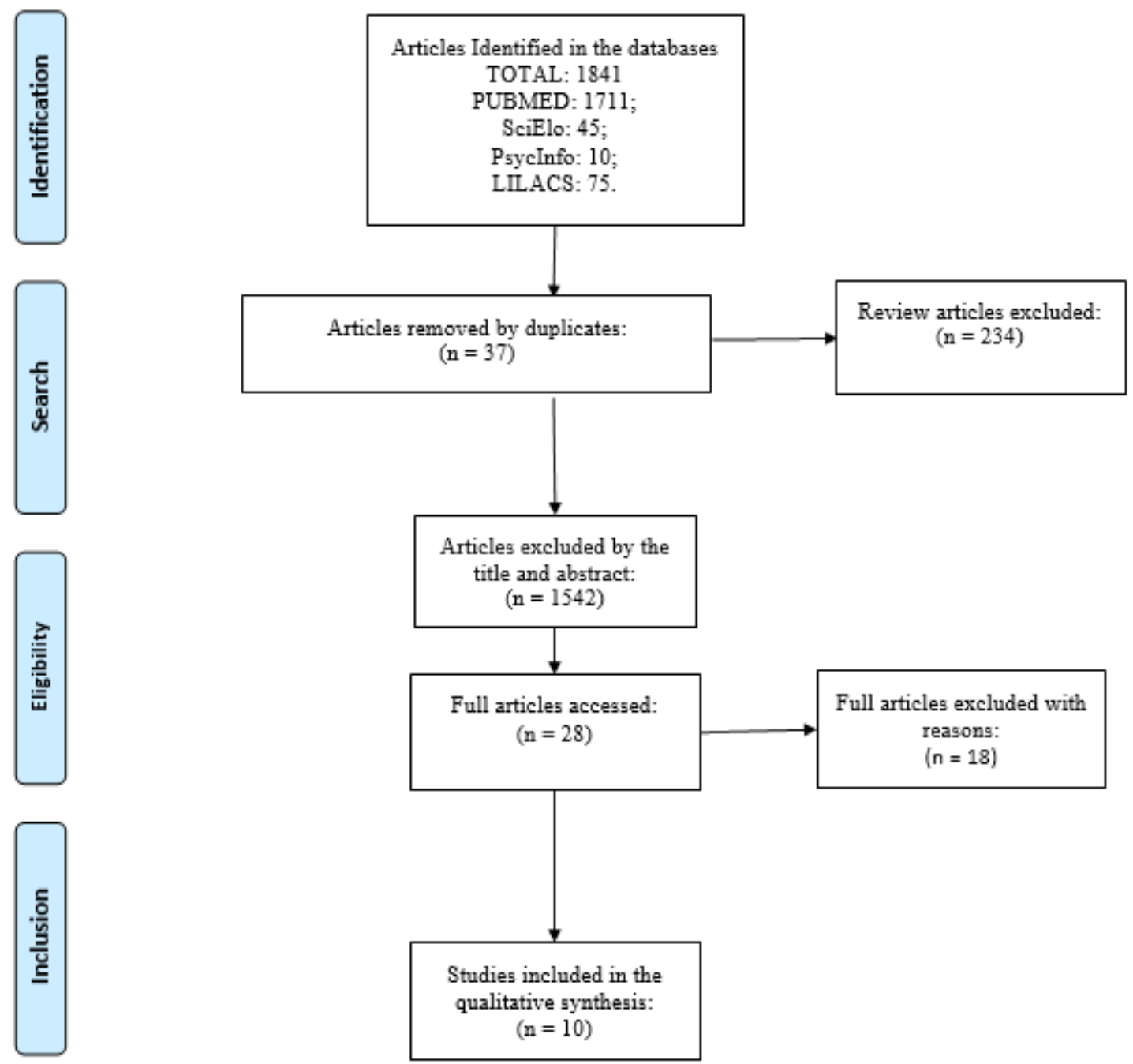

Source: Authors. 
Flowchart generated by PRISMA (Canadian-created widely used tool for data organizing in systematic reviews). The steps described comprise the number of studies selected and reasons for exclusion at each stage of literature review. From an initial amount of 1841 studies, only 10 met all inclusion criteria and were considered eligible for inclusion.

\section{Study description}

Of the 10 articles selected for this study, 1 was from Cuba (Fuentes, 2019), 2 from Argentina (Disalvo, n.d.; Riera et al., 2012), 1 from China (Hou et al., 2013), 2 from the USA (Keller et al., 2017; Roberts et al., 2013), 2 from India (Ansari et al., 2020; Goel \& Chowgule, 2019), 1 from Egypt (Mostafa et al., 2009) and 1 from Colombia (Carlos Mauricio Hurtado, Myriam Gutiérrez, 2007). Table 1 contains the major information of each study, namely blood lead levels, probable means of exposure, average age of assessed children and effects of lead on hematopoietic tissue and cognitive skills.

Table 1. Compilation of included studies describing high blood lead levels related to hematopoietic and cognitive effects in children.

\begin{tabular}{|c|c|c|c|c|c|c|}
\hline AUTHOR/YEAR & $\begin{array}{l}\text { COUNTRY } \\
\text { OF } \\
\text { ORIGIN }\end{array}$ & $\begin{array}{l}\text { N. OF NON } \\
\text { EXPOSED/ } \\
\text { EXPOSED } \\
\text { CHILDREN }\end{array}$ & $\begin{array}{l}\text { AGE } \\
\text { (Average/SD) } \\
\text { years }\end{array}$ & $\begin{array}{l}\text { BLOOD LEAD } \\
\text { CONCENTRATION }\end{array}$ & MEANS OF EXPOSURE & FINDINGS \\
\hline $\begin{array}{l}\text { Rodriguez- } \\
\text { Fuentes, } 2019\end{array}$ & Cuba & $0 / 12$ & $\begin{array}{l}1-6 \\
>6\end{array}$ & $\begin{array}{l}<10 \mu \mathrm{g} / \mathrm{dL}=2^{*} \\
10-24 \mu \mathrm{g} / \mathrm{dL}=9^{*} \\
25-45 \mu \mathrm{g} / \mathrm{dL}=1^{*} \\
10-24 \mu \mathrm{g} / \mathrm{dL} \text { (average) }\end{array}$ & $\begin{array}{l}\text { Children with parents who } \\
\text { worked with battery repair, } \\
\text { welsing, smelting, painting, } \\
\text { projectile factories or as } \\
\text { hatters }\end{array}$ & $\begin{array}{l}\text { A close correlation was } \\
\text { found between the values } \\
\text { of lead in the blood and } \\
\text { recurrent abdominal pain, } \\
\text { anorexia and iron } \\
\text { deficiency anemia. }\end{array}$ \\
\hline Riera et al., 2011 & Argentina & $0 / 7$ & $3-10$ & $\begin{array}{l}3 \text { years }=34.8 \mu \mathrm{g} / \mathrm{dL} \\
4 \text { years }=33 \mu \mathrm{g} / \mathrm{dL} \\
5 \text { years }=37.1 \mu \mathrm{g} / \mathrm{dL} \\
7 \text { years }=43.1 \mu \mathrm{g} / \mathrm{dL} \\
7 \text { years }=36.4 \mu \mathrm{g} / \mathrm{dL} \\
8 \text { years }=49.5 \mu \mathrm{g} / \mathrm{dL} \\
9 \text { years }=32.4 \mu \mathrm{g} / \mathrm{dL}\end{array}$ & $\begin{array}{l}\text { Residing close to a battery } \\
\text { factory (exposure via soil and } \\
\text { air) }\end{array}$ & $\begin{array}{l}\text { All children presented } \\
\text { microcytic hypochromic } \\
\text { anemia and } \\
\text { microalbuminuria, with } \\
\text { and average of } 10.2 \mathrm{~g} / \mathrm{dL} \\
\text { of hemoglobin. }\end{array}$ \\
\hline $\begin{array}{l}\text { Disalvo et al., } \\
2011\end{array}$ & Argentina & $0 / 93$ & $0.5-5$ & $\geq 10 \mu \mathrm{g} / \mathrm{dL}$ & $\begin{array}{l}\text { Living with family members } \\
\text { who carried out activities } \\
\text { involving lead handing }\end{array}$ & $\begin{array}{l}\text { The presence of levels } \\
\geq 10 \mu \mathrm{g} / \mathrm{dL} \text { in children's } \\
\text { blood was strongly } \\
\text { associated with iron } \\
\text { deficiency anemia }\end{array}$ \\
\hline Hou et al., 2013 & China & $100 / 96$ & $2-4(2.8 / 1.45)$ & $\begin{array}{l}76 \text { children: average } \\
\text { of } 88.39( \pm 67.92) \\
\mu \mathrm{g} / \mathrm{dl}\end{array}$ & $\begin{array}{l}\text { Dust containing lead in the } \\
\text { environment }\end{array}$ & $\begin{array}{l}\text { High blood lead levels } \\
\text { were negatively correlated } \\
\text { with the quotient of } \\
\text { development for adaptive } \\
\text { behavior, with language } \\
\text { and motor performance } \\
\text { and with social and } \\
\text { individual behavior, } \\
\text { effects leading to social } \\
\text { withdrawal, depression, } \\
\text { atypical body movements } \\
\text { and aggressive behavior }\end{array}$ \\
\hline $\begin{array}{l}\text { Roberts et al., } \\
2012\end{array}$ & USA & $77 / 64$ & $0-6$ & $\begin{array}{l}\geq 23 \mu \mathrm{g} / \mathrm{dL}=1^{*} \\
\leq 10 \mu \mathrm{g} / \mathrm{dL}=63^{*} \\
\geq 10 \mu \mathrm{g} / \mathrm{dL}=0^{*}\end{array}$ & $\begin{array}{l}\text { Exposure by paint used in } \\
\text { homes }\end{array}$ & $\begin{array}{l}\text { Learning deficts and } \\
\text { atypical behavior have } \\
\text { been linked to high blood } \\
\text { lead levels }\end{array}$ \\
\hline Goel et al., 2019 & India & $15 / 15$ & $0.5-13$ & Cases $= \pm 22.5 \mu \mathrm{g} / \mathrm{dL}$ & $\begin{array}{l}\text { Residing close to an } \\
\text { unorganized artificial jewelry } \\
\text { industry with the presence of }\end{array}$ & $\begin{array}{l}\text { Encephalopathy, seizures } \\
\text { and drowsiness were } \\
\text { found in children who had }\end{array}$ \\
\hline
\end{tabular}


Research, Society and Development, v. 10, n. 7, e37410716616, 2021

(CC BY 4.0) | ISSN 2525-3409 | DOI: http://dx.doi.org/10.33448/rsd-v10i7.16616

\begin{tabular}{|c|c|c|c|c|c|c|}
\hline & & & & Controls $= \pm 1.2 \mu \mathrm{g} / \mathrm{dL}$ & aerosolized lead & $\begin{array}{l}\text { average lead levels of } \\
42.6 \pm 22.5 \mu \mathrm{g} / \mathrm{dL} \text {, } \\
\text { indicating probable acute } \\
\text { lead poisoning }\end{array}$ \\
\hline $\begin{array}{l}\text { Mostafa et al., } \\
2019\end{array}$ & Egypt & $\begin{array}{l}50 / 50 \\
50=\text { Areas } \\
\text { highly } \\
\text { polluted by } \\
\text { lead } \\
50=\text { Polluted } \\
\text { areas with } \\
\text { low levels of } \\
\text { lead }\end{array}$ & $\begin{array}{l}10(3-12) \pm \\
1.98\end{array}$ & $\begin{array}{l}\text { Areas highly polluted } \\
\text { by lead: } \\
\geq 20 \mu \mathrm{g} / \mathrm{dL}=6^{*} \\
\geq 25 \mu \mathrm{g} / \mathrm{dL}=2^{*} \\
\text { Polluted areas with } \\
\text { low levels of lead: } \\
\leq 10 \mu \mathrm{g} / \mathrm{dL}\end{array}$ & $\begin{array}{l}\text { Contact with dust present in } \\
\text { highly polluted areas }\end{array}$ & $\begin{array}{l}\text { Significant association } \\
\text { between increased levels } \\
\text { of lead in the blood and } \\
\text { decreased cognitive } \\
\text { function }\end{array}$ \\
\hline Ansari et al., 2020 & India & $100 / 41$ & $7(3-12)$ & $\begin{array}{l}<5 \mu \mathrm{g} / \mathrm{dL}=4^{*} \\
5-20 \mu \mathrm{g} / \mathrm{dL}=17^{*} \\
>20 \mu \mathrm{g} / \mathrm{dL}=20^{*} \\
\text { Minimum } \\
\text { concentration found }= \\
9.1 \mu \mathrm{g} / \mathrm{dL} \\
\text { Maximum } \\
\text { concentration found }= \\
80 \mu \mathrm{g} / \mathrm{dL}\end{array}$ & $\begin{array}{l}\text { Contact with dust and soil } \\
\text { residing near informal battery } \\
\text { recycling workshops }\end{array}$ & $\begin{array}{l}\text { Decrease } \mathrm{Hb} \text { in } \\
\text { individuals with high } \\
\text { blood lead concentration. } \\
\text { Children with blood } \\
>5 \mu \mathrm{g} / \mathrm{dL} \text { showed } \\
\text { hyperactivity, reduced } \\
\text { learning performance, } \\
\text { tiredness, headaches, } \\
\text { lethargy and abdominal } \\
\text { pain. In all samples, } \\
\text { hemoglobin levels ranged } \\
\text { from } 7.8 \mathrm{~g} / \mathrm{dL} \text { to } 12.0 \mathrm{~g} / \mathrm{dL} \\
\text { in children with blood } \\
\text { lead levels }>5 \mu \mathrm{g} / \mathrm{dL}\end{array}$ \\
\hline Hurtado et., 2007 & Colombia & $68 / 32$ & $\begin{array}{l}0-12 \\
\text { Average }=7\end{array}$ & $\begin{array}{l}\geq 10 \mu \mathrm{g} / \mathrm{dL}=22^{*} \\
>70 \mu \mathrm{g} / \mathrm{dL}=10^{*}\end{array}$ & $\begin{array}{l}\text { Dust and smoke from burnt } \\
\text { paint, smelting or recycling } \\
\text { of batteries and deteriorated } \\
\text { lead paint chips found on the } \\
\text { inside walls of houses }\end{array}$ & $\begin{array}{l}\text { All children had } \\
\text { unacceptable levels of } \\
\text { blood lead, presenting } \\
\text { anemia, hypoxia, } \\
\text { abdominal pain, recurrent } \\
\text { headaches, saturnism, } \\
\text { mucocutaneous pallor and } \\
\text { other conditions, such as } \\
\text { poor school }\end{array}$ \\
\hline Keller et al., 2016 & USA & $0 / 145$ & $0-6(3.85)$ & $>45 \mu \mathrm{g} / \mathrm{dL}$ & $\begin{array}{l}\text { Exposure by paint used in } \\
\text { homes }\end{array}$ & $\begin{array}{l}\text { Associations have been } \\
\text { found between lead } \\
\text { poisoning and effects such } \\
\text { as anemia and } \\
\text { developmental } \\
\text { impairments, such as } \\
\text { autism. Some children } \\
\text { presented sickle cell } \\
\text { disease, which in one of } \\
\text { the risk factors for the risk } \\
\text { factors for the } \\
\text { aforementioned } \\
\text { conditions }\end{array}$ \\
\hline
\end{tabular}

Source: Authors.

The table compiles the studies included in the present work. India, the USA and Latin America were the regions reporting the greater number of studies, Latin America with the highest number of studies (4). It must be noted that some articles provide strong support on their findings regarding lead symptoms, such as seen in the works by Hou et al., (2012) and Roberts et al., (2013), due to these works showing comparisons between exposed and non-exposed populations, which were 
not reported by all of the studies. Also, while the overall manner blood lead levels are reported is similar for each work, some provide greater detail by stratifying blood lead levels by age or by describing the number of children at certain thresholds of blood lead levels. The last column provides short conclusions made by the authors of the present work in an attempt to evidence the main observations regarding blood levels and symptoms as described by the original authors throughout their studies. *Lead Concentration= Number of children; $\mathrm{N}=$ Number abbreviation

\section{Children, lead and means of exposure}

Data collected represent 964 children (555 presenting high blood lead levels and 409 non-exposed controls). The age of the children ranged from 0 to 13 years; lead levels ranged from $4 \mu \mathrm{g} / \mathrm{dL}$ to values up to $88 \mu \mathrm{g} / \mathrm{dL}$ in exposed children. Lead exposure was found to be due to contact with soil, water or air containing lead, which happened due to children living in areas close to accumulator industries; exposure was also reported to occur due to children living with parents or other family members who carry out activities involving lead handling or who work with battery repair, welding, foundry, painting, projectile factories or as hatters, or through contact with deteriorated paint chips containing lead found on the internal walls of houses (Ansari et al., 2020; Carlos Mauricio Hurtado, Myriam Gutiérrez, 2007; Disalvo, n.d.; Fuentes, 2019; Goel \& Chowgule, 2019; Hou et al., 2013; Keller et al., 2017; Mostafa et al., 2009; Riera et al., 2012; Roberts et al., 2013).

\section{Effects of elevated blood lead levels}

The main effects of lead intoxication were reported to take place upon the hematopoietic tissue and in the central nervous system leading to cognitive disorders. It was possible to verify that lead levels ranging from $\leq 10 \mu \mathrm{g} / \mathrm{dL}$ to $80 \mu \mathrm{g} / \mathrm{dL}$ are related to iron deficiency anemia (Disalvo, n.d.; Fuentes, 2019), microcytic hypochromic anemia, microalbuminuria (Riera et al., 2012) and decreased hemoglobin level (Ansari et al., 2020). Children presenting lead levels ranging from $4 \mu \mathrm{g} / \mathrm{dL}$ up to $88.39 \mu \mathrm{g} / \mathrm{dL}$ were reported to suffer from learning deficiencies, impairments of adaptive, language, motor, social and individual behaviors alongside depression, atypical body movements, hyperactivity, tiredness, headaches, lethargy and aggression (Ansari et al., 2020; Hou et al., 2013; Mostafa et al., 2009; Roberts et al., 2013). In addition, symptoms such as recurrent abdominal pain, anorexia, recurrent headache, saturnism and mucocutaneous pallor (Ansari et al., 2020; Carlos Mauricio Hurtado, Myriam Gutiérrez, 2007; Fuentes, 2019) have also been reported. Finally, blood lead levels as high as 42.6 $\pm 22.5 \mu \mathrm{g} / \mathrm{dL}$ were reported to be associated with encephalopathy (Goel \& Chowgule, 2019). In children who had autism or sickle cell anemia, lead levels higher than $45 \mu \mathrm{g} / \mathrm{dL}$ were reported (Keller et al., 2017).

\section{Discussion}

In this review, we have gathered data regarding lead poisoning in children highlighting certain key findings. First, the results evidence there is a relationship between blood lead levels, effects in the hematopoietic system and cognitive functions in children exposed to lead, even at low levels. Secondly, although lead poisoning in children is an issue that has endured for decades, it is still a recurrent and serious public health issue worldwide, given that many of the analyzed articles had been published in recent years. As such, Ahmadi et al., 2020 report blood levels higher than $100 \mu \mathrm{g} / \mathrm{dL}$ in $14.4 \%$ of 425 analyzed children, and $59.9 \%$ of them presenting blood lead levels higher than $50 \mu \mathrm{g} / \mathrm{dL}$ in sub-Saharan Africa (Ahmadi et al., 2020). Charkiewicz et al., 2020 indicate the importance of creating public policies addressing minimization of lead exposure in the workplace and at home (Charkiewicz \& Backstrand, 2020).

Charkiewicz et al., 2020 also report that damage to children caused by lead intoxication can occur as early as during pregnancy, when exposure to lead occurs from mother to fetus through the placenta; pregnant women who had been previously exposed to lead can release any accumulated metal directly into the bloodstream eventually reaching the fetus, 
especially if the mother's calcium intake is low. Fetal development can thus be influenced by both present and past exposure of the mother to lead, and since lead can be accumulated in cortical bone for years, newborn children are prone to develop symptoms associated with exposure to lead right after birth into infancy and adolescence (Charkiewicz \& Backstrand, 2020).

According to the scientific literature, exposure to lead can either be occupational, environmental (through contact with contaminated air, dust, food or water) or due to contact with products containing lead such as gasoline and paints (Ministério da Saúde, 2017a). Respiratory and gastrointestinal organs are the major systems through which lead absorption occurs. After being absorbed, lead can be found in blood and in soft and mineralized tissues, bones being the main lead deposit where up to $90 \%$ of total body levels can be accumulated (F. R. J. C. M. Moreira, 2004).

Lead exposure leads to neurological effects, the impairment of children development being the most critical (F. R. Moreira \& Moreira, 2004). Children exposed to lead have shown disturbances in adaptive behavior and in motor, social and individual performances in addition to depression, atypical body movements, poor academic performance and developmental delays, including conditions such as autism and hyperactivity, the latter being associated with blood lead levels above $5 \mu \mathrm{g} / \mathrm{dL}$. Other conditions, such as sleep disorders, aggressive behavior, and even encephalopathy have been reported to be associated with high blood lead levels in children.

Regulatory agencies report that lead accumulation in the body is due to long-term exposure (Ministério da Saúde, 2017b), which can lead to chronic toxicity (Ramos et al., 2009). Adverse effects were observed in the neurological, renal, cardiovascular, hematological, immunological and reproductive systems in children presenting blood lead levels close to 10 $\mu \mathrm{g} / \mathrm{dL}$. No safe lead levels have ever been identified regarding such effects, and cognitive deficits are observed in children at lead levels as low as $5 \mu \mathrm{g} / \mathrm{dL}$. All data gathered so far are also insufficient to allow reliable dose-response relationships inferences to be made (Services, 2002). In view of this scenario, the use of lead is restricted in many countries and even prohibited In Canada, United States of America and England since 1997, 1993 and 1987, respectively, when the first laws on lead use and exposure were created (Planejamento \& Urbano, 2004). In Brazil, however, it was only after the 1990s that lead began to be removed from materials, starting with gasoline in 1992, and partially removed from paint products in 2008 (Agência Nacional de Petróleo, 2020; Do et al., 2002; Ministério do desenvolvimento, Indústria e comércio exterior. Instituto nacional de metrologia, 2015; Planejamento \& Urbano, 2004).

There are a number of countries, Brazil among them, which do not have their own Limits of Biological Tolerance (LBT) for lead exposure and usually adopt criteria defined by other nations in order to circumvent such limitation. In Brazilian's legislation there is only one Regulatory Norm (Number 7 Regulatory Norm), which dictates for workers a LBT of $60 \mu \mathrm{g} / \mathrm{dL}$ for lead exposure (Trabalho, 2020). Therefore, there is no corresponding regulation concerning lead poisoning in children. There is also considerable divergence regarding tolerance values adopted by different countries, making the comparison of limits for lead exposure values extremely difficult, even more so for children.

Even though scientific studies on lead toxicity have been carried out now for more than a century, there are still many unresolved matters. There is little information on all of the mechanisms of action responsible for the toxic effects of lead, limiting the actions that can be taken by policy makers to prevent all of such effects, and thus further research on this topic is still necessary (F. R. Moreira \& Moreira, 2004). The information compiled in this review showed that exposure to lead, especially at high levels, leads to toxic effects in children which are directly related to the hematopoietic system and to cognitive functions. Many of such toxic effects caused by lead poisoning are due to the ability of lead to replace calcium, zinc and other divalent cations in certain enzymes, compromising molecular pathways. Although a number of these effects are due to direct interaction of lead with cellular components, others are caused by more complex processes, involving changes in gene regulation, protein synthesis or energy metabolism, which go way beyond mere structural interaction with other proteins (Garza et al., 2006). Under certain circumstances, lead poisoning can lead to dangerous scenarios; Keller et al. 2016 reported 
cases of children suffering from lead poisoning who had developed autism or sickle cell anemia, this being possibly linked to dysfunctional eating patterns caused by lead intake, which in turn leads to even more lead intake (Keller et al., 2017).

Based on the studies here presented, it is noticeable that the majority of them were conducted in Latin American countries, which evidences lead contamination is still a persistent issue in such countries, as the European Union has either banned or limited the amount of lead in materials as early as 1920 (Europeu, n.d.).

\section{Conclusion}

The data here gathered can provide further basis for both researchers and policy makers to better guide future efforts aimed at addressing the issue of lead poisoning in children. Knowing at which levels lead is reported to lead to either hematopoietic or cognitive harmful effects in children as well as its means of exposure allows for more precise monitoring of high-risk areas in a practical manner by public health agencies. It also allows research in said areas to be more focused and more easily corroborated with the studies here given. Even though there is a number of works on lead poisoning in children in Latin America, studies tackling this issue carried out in Brazil are still scarce; we hope this work encourages researchers to try and identify areas of greater risk for lead poisoning in children and assess likely symptoms in correlation with blood lead levels, as we are convinced our work provides a framework for such research to be carried out.

Thus, the assessment of toxic metals in the study of the etiology of diseases in children is imperative; lead poisoning is still a serious public health concern, especially for children, and advancement on the knowledge regarding areas of greater risk for lead exposure and regarding which populations are affected by such exposure is crucial for public health agencies and policy makers to better address this issue.

\section{References}

Agência Nacional de Petróleo, G. N. e B. (ANP). (2020). Gasolina- PETROBRAS. https://petrobras.com.br/pt/nossasatividades/produtos/automotivos/gasolina/

Ahmadi, S., Bot, B. Le, Zoumenou, R., Durand, S., Fiévet, N., Ayotte, P., Massougbodji, A., Alao, M. J., Cot, M., Glorennec, P., \& Bodeau-Livinec, F. (2020). Follow-up of elevated blood lead levels and sources in a cohort of children in Benin. International Journal of Environmental Research and Public Health, 17(22), 1-15. https://doi.org/10.3390/ijerph17228689

Altman, D. (2015). Principais itens para relatar Revisões sistemáticas e Meta-análises: A recomendação PRISMA. Epidemiologia e Serviços de Saúde, 24(2), 335-342. https://doi.org/10.5123/s1679-49742015000200017

Ansari, J. A., Mahdi, A. A., Malik, P. S., \& Jafar, T. (2020). Blood lead levels in children living near an informal lead battery recycling workshop in Patna, Bihar. Journal of Health and Pollution, 10(25), 1-9. https://doi.org/10.5696/2156-9614-10.25.200308

Carlos Mauricio Hurtado, Myriam Gutiérrez, J. E. (2007). Aspectos clínicos y niveles de plomo en niños expuestos de manera paraocupacional en el proceso de reciclaje de baterías de automóviles en las localidades de Soacha y Bogotá, D.C. Journal of Chemical Information and Modeling, 53(9), 1689-1699.

Charkiewicz, A. E., \& Backstrand, J. R. (2020). Lead toxicity and pollution in Poland. International Journal of Environmental Research and Public Health, 17(12), 1-16. https://doi.org/10.3390/ijerph17124385

Chiodo, L. M., Jacobson, S. W., \& Jacobson, J. L. (2004). Neurodevelopmental effects of postnatal lead exposure at very low levels. Neurotoxicology and Teratology, 26(3), 359-371. https://doi.org/10.1016/j.ntt.2004.01.010

Costa, C., Araujo, E., Olivieri, R. D., Ribeiro, M. I. F. C. A., \& Oliveira, R. L. (2012). Casos paradigmáticos sobre contaminação provocada por chumbo em várias regiões do mundo. Santo Amaro, 191-221.

Dascanio, D., Fontaine, A. M. G., Maria, O., Rodrigues, P. R., \& Prette, Z. A. P. Del. (2012). The intellectual and academic performance of adolescents contaminated by lead: relation with social skills Desempenho intelectual e acadêmico de adolescentes contaminados por chumbo: relação com as habilidades sociais El rendimiento intelectual y académ. 20(1), 45-59.

Dascanio, D., Prette, Z. A. P. Del, Rodrigues, O. M. P. R., \& Prette, A. Del. (2016). Intoxicação infantil por chumbo: uma questão de saúde e de políticas públicas TT - Childhood lead poisoning: a health issue and public policy TT - Intoxicación infantil por plomo: una cuestión de salud y de políticas públicas. Psicol. Rev. (Belo Horizonte), 22(1), 90-111. http://pepsic.bvsalud.org/scielo.php?script=sci_arttext\&pid=S1677-11682016000100007

Disalvo, L. et al. (n.d.). Plumbemia En Niños En La Ciudad de La Plata, Argentina y Su Relación Con la Deficiencia de Hierro y los Factores de Exposición Al Plomo.

Do, a E., Da, C., Jorge, P., \& Figueiredo, M. (2002). $5^{\circ}$ Congresso de Pós-Graduação A ELIMINAÇÃO DO CHUMBO DA GASOLINA. 1-6. 
Europeu, P. (n.d.). Proibição de Chumbo UE. https://www.europarl.europa.eu/sides/getDoc.do?pubRef=-//EP//TEXT+WQ+E-20090674+0+DOC+XML+V0//PT

Freudenrich, C. (2009). How Lead Works. How Lead Works. https://science.howstuffworks.com/lead.htm

Fuentes, T. R. (2019). Comportamiento del plomo sérico en niños expuestos de la ciudad de Camagüey. Revista Archivo Médico de Camagüey, 23(1), 64-74.

Gao, Z., Cao, J., Yan, J., Wang, J., Cai, S., \& Yan, C. (2017). Blood Lead Levels and Risk Factors among Preschool Children in a Lead Polluted Area in Taizhou, China. BioMed Research International, 2017. https://doi.org/10.1155/2017/4934198

Garza, A., Vega, R., \& Soto, E. (2006). Cellular mechanisms of lead neurotoxicity. Medical Science Monitor, 12(3), 57-65.

Goel, A. D., \& Chowgule, R. V. (2019). Outbreak investigation of lead neurotoxicity in children from artificial jewelry cottage industry. Environmental Health and Preventive Medicine, 24(1), 1-5. https://doi.org/10.1186/s12199-019-0777-9

Hou, S., Yuan, L., Jin, P., Ding, B., Qin, N., Li, L., Liu, X., Wu, Z., Zhao, G., \& Deng, Y. (2013). A clinical study of the effects of lead poisoning on the intelligence and neurobehavioral abilities of children. Theoretical Biology and Medical Modelling, 10(1), 1-9. https://doi.org/10.1186/1742-4682-10-13

IBGE. (n.d.). As crianças no Brasil. https://educa.ibge.gov.br/criancas/brasil/nosso-povo/20785-as-criancas-no-brasil.html

Keller, B., Faciano, A., Tsega, A., \& Ehrlich, J. (2017). Epidemiologic Characteristics of Children with Blood Lead Levels $\geq 45 \mu \mathrm{g} / \mathrm{dL}$. Journal of Pediatrics, 180, 229-234. https://doi.org/10.1016/j.jpeds.2016.09.017

Landrigan, P. J., Schechter, C. B., Lipton, J. M., Fahs, M. C., \& Schwartz, J. (2002). CHILDREN' S HEALTH Environmental Pollutants and Disease in American Children : Estimates of. Environmental Health Perspectives, 110(7), 721-728.

Lanphear, B. P., Hornung, R., Khoury, J., Yolton, K., Baghurst, P., Bellinger, D. C., Canfield, R. L., Dietrich, K. N., Bornschein, R., Greene, T., Rothenberg, S. J., Needleman, H. L., Schnaas, L., Wasserman, G., Graziano, J., \& Roberts, R. (2005). Low-level environmental lead exposure and children's intellectual function: An international pooled analysis. Environmental Health Perspectives, 113(7), 894-899. https://doi.org/10.1289/ehp.7688

Liu, K. S., Hao, J. H., Zeng, Y., Dai, F. C., \& Gu, P. Q. (2013). Neurotoxicity and biomarkers of lead exposure: A review. Chinese Medical Sciences Journal, 28(3), 178-188. https://doi.org/10.1016/S1001-9294(13)60045-0

Mayans, L. (2019). Lead poisoning in children. Social Work (United States), 19(4), 509. https://doi.org/10.1093/sw/19.4.509-a

Ministério da Saúde. (2017a). Chumbo. https://www.gov.br/saude/pt-br\#: :text=A exposição humana ao chumbo,tintas\%2C maquiagem\%2C etc).

Ministério da Saúde. (2017b). Efeitos do Chumbo. https://www.gov.br/saude/pt-br\#: :text=Além disso\%2C outros sinais e,pequeno aumento da pressão arterial $\% 3 \mathrm{~B}$

Ministério do desenvolvimento, Indústria e comércio exterior. Instituto nacional de metrologia, qualidade e tecnologia - I. (2015). Relatório De Análise De Chumbo Em Tintas. 1-23. http://www.inmetro.gov.br/consumidor/produtos/chumbo-em-tintas.pdf

Moreira, F. R. J. C. M. (2004). A cinética do chumbo no organismo humano e sua importância para a saúde Lead kinetics in human body and its significance to health. 9(1), 167-181.

Moreira, F. R., \& Moreira, J. C. (2004). Os efeitos do chumbo sobre o organismo humano e seu significado para a saúde. Revista Panamericana de Salud Pública, 15(2), 119-129. https://doi.org/10.1590/s1020-49892004000200007

Mostafa, G. A., El-Shahawi, H. H., \& Mokhtar, A. (2009). Blood lead levels in Egyptian children from high and low lead-polluted areas: Impact on cognitive function. Acta Neurologica Scandinavica, 120(1), 30-37. https://doi.org/10.1111/j.1600-0404.2009.01155.x

Needleman, H. (2004). Lead poisoning. Annual Review of Medicine, 55(1), 209-222. https://doi.org/10.1146/annurev.med.55.091902.103653

Padula, N. A. de M. R., Abreu, M. H. de, Miyazaki, L. C. Y., \& Tomita, N. E. (2006). Intoxicação por chumbo e saúde infantil: ações intersetoriais para o enfrentamento da questão. Cadernos de Saúde Pública, 22(1), 163-171. https://doi.org/10.1590/s0102-311x2006000100017

Page, M. J., McKenzie, J. E., Bossuyt, P. M., Boutron, I., Hoffmann, T. C., Mulrow, C. D., Shamseer, L., Tetzlaff, J. M., Akl, E. A., Brennan, S. E., Chou, R., Glanville, J., Grimshaw, J. M., Hróbjartsson, A., Lalu, M. M., Li, T., Loder, E. W., Mayo-Wilson, E., McDonald, S., ... Moher, D. (2021). The PRISMA 2020 statement: An updated guideline for reporting systematic reviews. The BMJ, 372. https://doi.org/10.1136/bmj.n71

Planejamento, N. De, \& Urbano, R. (2004). Projeto de Lei $n^{\circ}$ 3.460, de 2004. 2004, 1-39.

Prevention, U. C. for D. C. and. (2020). Blood Lead Reference Value. https://www.cdc.gov/nceh/lead/data/blood-lead-reference-value.htm

Ramos, W., Munive, L., Alfaro, M., Calderón, M., Gonzáles, I., \& Núñez, Y. (2009). Intoxicación plúmbica crónica: una revisión de la problemática ambiental en el Perú Chronic lead poisoning : a review of the environmental peruvian problem. 13, 1-8.

Riera, N. M., Feldman, G., Granger, S., Chain, S., \& Soria, N. (2012). Lead intoxication: Clinic and diagnostic evaluation in children. Revista Ciencias de La Salud, 10(SPECIAL ISSUE), 9-15.

Roberts, J. R., Allen, C. L., Ligon, C., \& Reigart, J. R. (2013). Are children still at risk for lead poisoning? Clinical Pediatrics, 52(2), 125-130. https://doi.org/10.1177/0009922812464549

Schifer, T. D. S., Junior, S. B., \& Montano, M. A. E. (2005). Aspectos toxicológicos do chumbo. Informa, 17(5/6), 67-72. 
Research, Society and Development, v. 10, n. 7, e37410716616, 2021

(CC BY 4.0) | ISSN 2525-3409 | DOI: http://dx.doi.org/10.33448/rsd-v10i7.16616

Services, D. of H. and H. (2002). Toxicological Profile for Lead. ATSDR's Toxicological Profiles, August. https://doi.org/10.1201/9781420061888_ch106

Souza, A. M., \& Tavares, C. F. F. (2009). Chumbo e anemia. Medicina, 42(3), 327-330. https://doi.org/10.11606/issn.2176-7262.v42i3p337-340

Trabalho, M. da J. e S. P. de saúde e segurança no. (2020). NR 7 ATUALIZADA. Journal of Chemical Information and Modeling, 21(1), 1-9. https://doi.org/10.1016/j.tmaid.2020.101607\%0Ahttps://doi.org/10.1016/j.ijsu.2020.02.034\%0Ahttps://onlinelibrary.wiley.com/doi/abs/10.1111/cjag.12228\%

0Ahttps://doi.org/10.1016/j.ssci.2020.104773\%0Ahttps://doi.org/10.1016/j.jinf.2020.04.011\%0Ahttps://doi.o

UNICEF. (2020). The Toxic Truth: Children's exposure to lead pollution undermines a generation of future potential. The Toxic Truth: Children's Exposure to Lead Pollution Undermines a Generation of Future Potential. https://www.unicef.org/reports/toxic-truth-childrens-exposure-to-lead-pollution-2020 